\title{
Jordanian Musiqa Sha'abie: An Expression of Ethnical Authenticity in the Stream of Global Pop Music
}

\author{
Tsonka Al Bakri \\ School of Art and Design, The University of Jordan, Amman 11942, Jordan
}

\begin{abstract}
This paper aims to establish some theoretical links between ethnical self-identification, popular culture, and the concept of heritage tradition. Live music in contemporary Hashemite Kingdom of Jordan links to and is observed as based on local songs, otherwise known as Sha'abie. Thus, this article will investigate the combination of contextual, traditional, geographic, and religious factors, assisting the cultural comprehension of a Musiqa Sha'abie. It will answer the questions of why and how the musiqa sha'abie finds its principal place within the framework of popular music in Jordan, meanwhile providing new insights into the problem of how music constructs and defines identities. Synchronically, the paper will explain how the Jordanian music has been shifted from its rural roots and thus becoming Westernized, a product of globalization, and an aesthetic reflection of complex manifestation of stereotyped cultural homogeneity. Accordingly, I will trace the impact of the social and historical background of Jordanian culture into its broader context of postmodern music to find legitimacy to the local pop expression, referred to as Sha'abie.
\end{abstract}

Keywords: ethnos, musiqa sha'abie, dabkeh, gina al horani, Jordanian pop music, maqam

DOI: $10.7176 / \mathrm{JEP} / 11-23-07$

Publication date:August $31^{\text {st }} 2020$

\section{Introduction}

The principal aim of this article is to discuss pop music as a global phenomenon far more complicated than a form of modernity or a mere commodity. As Erlmann puts it, "[It] is a new aesthetic form of the global imagination" (Erlmann, 1996, 468). We live with music. Music surrounds us throughout the span of our lives and exerts a substantial impact on our identities. The music as subject of an ontological scientific query represents who we are, where we come from, what our culture is, and what values we adopt. As Frith argues, "It needs stressing that what people listen to is more important for their sense of themselves than what they watch or read. Patterns of music use provide a better map of social life than viewing or reading habits. Music matters more than any other medium" (Frith, 2007, 205). The manifestation of local popular culture is what forms the social consciousness; it is the allencompassing principle that defines the collective self-awareness of an ethos.

When popular music is referenced in academic literature, it tends to deviate towards homogenization, or "fusion of horizons which operates though developing new methods of approach, new vocabularies, by which one can articulate these contrasts" (Taylor, 1994, 67). A body of researches dedicated to popular music emerged last decades. Thanks to scholars, such as Marriam, Becker, Tagg, Frith, Kerman, Kramer, and Blacking, music has increasingly become associated with behavior, tradition, beliefs, inter-group dynamics, socio-normativity, as well as social processes and global economic. Contemporary musicology ponders about how music is distributed between different social groups and how it relates to geographic regions, religions, ethnicities, identities, classes, genders, and age groups. Furthermore, it addresses the role of the mass media in dispensing music to its audience. Drawing on similar theoretical frameworks that are utilized in place and space, this article will investigate the significance of a specific style of music. This aim will be accomplished by qualitative, exploratory research conducted to determine the nature of musiqa sa'abie, on which little research has been done.

Culture and its effects on re-shaping musical practices is the key to fully comprehend the place of musiqa sha'abie within the Jordanian society. This understanding begins with identifying some basic paradigms of Arabic music, and more particularly, the classical Arabic music, otherwise known as musiqa al tarab. Musiqa al tarab has developed based on the traditional maqam system and is performed by takht, (traditional Arabic ensemble). The most prominent singers of the musiqa tarab were: Abedl Halim Hafez (1929-1977), Asmahan (1912-1944), Farid al Atrash (1910-1074), and Umm Kulthum (1898-1975). With the spreading of television broadcasting and the expansion of Western culture via media export, the Arabic musical tradition was subjected to an in-depth process of adaption toward Western cultural influence. Free access to foreign musical products (via tape cassettes and CDs) inspired local artists to modernize their music, "using new formats that insured public interest" (Mutaz, 2010, 81). Late twenty- and early twenty-first centuries brought forth satellite channels such as: Arabsat and Nilesat, Internet, and mobile technology. All these factors collectively had a far-reaching impact on contemporary Arab music, which has adapted into a new form of homogeneous pop, a byproduct embedded in Western trends and locality. Key representatives of this music stream are Nancy Ajram, Najwa Karam, Amr Diab, George Wassouf, Elissa, and Fadel Shaker. These leading mutribeen (artists) songs are inherently Westernized, and can be described as a reflection of inter-cultural dialogue, as studied by Radano and Bohlman, Shannon, Holt, 
Frishkopf, Schade-Poulsen, Cachia, Saada-Ophir, Danielson, Marcus, Rasmussen, Lohman, and Marcus. Contemporary musicians exhibit a style that can be described as a coherence of cultural continuity and cultural hybridity; style, which by media domination created new Arab popular music; a style that no longer correspond to musiqa al tarab. It is presently known as musiqa jadidah (the new music). Egyptian variant of musiqa jadidah was studied by Daniel Gilman (2014) and was defined as al musiqa al shababiyya or (the music of the youth). Precisely, musiqa jadidah granted a voice to the new spiritual up-swing towards cultural exchange and freedom. In some research, for instance, in LeVine's study concerning Heavy Metal in MENA, Iran, and Pakistan, the author proclaims the modern pop culture as a declaration of a new aesthetic and voice of "resistance" (LeVine, 2008, 11,12). Considering LeVine's statement, one may question whether the strive for cosmopolitan plurality and Western sound can be declared a form of 'resistance' or more simply can be observed an attempt to emancipation, and modernity of a young, internet-savvy generation. Alternatively, discussing the same phenomenon, Baker argues, that new music and its associated dance, represent liberation from social, political, and even economic constraints (Baker, 2011, 137). Simultaneously, it seems unreasonable to claim that political influence in art and music does not exist (Mostafa, 2012; Mitchell, 2002). There are artists, (Ali el Haggar, El General, Hazem Shaheen, and Samia Jaheen) who articulated social and political problems. Nevertheless, the deep coloration in musiqa jadidah can be deemed as being oriented toward crossing borders, reaching different 'others,' rather than being a declaration of political tendencies. Musiqa jadidah is urban-centered music, an expression of an intense lust for modernization and globalization. This particular thirst for multiculturalism can be referred to Burdon and Neff: "In all case, the authors of these pages listen for politics that don't always read as protest, for aesthetics that resist codification, for music that moves through cities and backgrounds, studios and clubs, empires and colonies, bodies' politics and biology. They tune our ears to how the Global South sounds" (Burdon and Neff, 2016, 385). In that sense, musiqa jadidah, can be seen as an open pot wherein tradition co-exist alongside new ideas and aesthetics coming from the West, which are constantly intertwined, therefore creating a unique situation, which require to be closely observed and analyzed.

Alongside the rise of musiqa jadidah, an intriguing development of a third music style can be observed. This style is based on the Arab folklore and receives various levels of attention among the Arab countries. The geographic exclusivity stems from the fact that the musical phenomenon found its roots in local cultural and social occurrences, historical events, and regional heritages, which are, in turn, formed into themes of the pop songs. A Hijazi (region in Saudi Arabia) locals would not fully comprehend the meanings found within an Irbid (Northern Jordanian region) songs and vice versa. Musiqa sha'abie, known in Jordan as 'music of the people,' is characterized using specific instruments, texts, sound, and visualization, which distinguishes it from the musiqa jadidah or musiqa al tarab. Musiqa sha'abie is based on local folk roots and is addressed to and accepted by all various sub-groups within the Jordanian society. This article responds to the questions raised in the musical contestation of how particular musical elements are recombined and transformed to produce a new popular style. In this context, I will observe the expression of musiqa sha'abie within the frontiers of Jordan as a medium, simultaneously verbalizing two paradigms: traditional and popular. Accordingly, this paper will examine the essential components which outline the boundaries of the analyzed object. In other words: "The field would seem to comprise three related elements: a body of music, those who perform it, and the way in which the performers approach the music" (Kelly, 1989, 2).

\section{Music Pop Culture in the Arab World}

Following the postcolonial period, the Arab-Israeli wars of 1948 and 1967, the Lebanese Civil War of 1975, the Iraq-Iran war 1980-1988, the Palestinian Intifada of 1988, the Gulf War of 1991, as well as the Arab Spring and the political crises after that, one can sense an increasing maturity of Arab ideological self-determination. The process is believed to have initiated in the early twentieth century following the al thaura al arabie al kubra (Great Arab Revolution), at which point the Arab States descended from the Ottoman Empire. Subsequently, the new countries were formed in the fertile-crescent, along with signing the Sykes-Picot Agreement and the partitioning of former Ottoman territories. These following events defined the territorial and national sovereignty of the hitherto non-existing Arab States, which inevitably led to Pan-Arabism. The Pan-Arabism could be described as a counter Pax-Arabica or the Middle East's political and ideological fragmentation. The socio-dynamic of these movements brought the demand for constitutionalizing different cultural identities. In this context, one can quote Bhabha, who noted that "to reconstitute the cultural difference demands not simply a change of cultural contents and symbols. It requires a radical revision of the social temporality in which emergent histories may be written, the rearticulating of the 'sign' in which cultural identities may be inscribed" (Bhabha, 1994, 171). The following self-shaping processes of ethnical, cultural, and socio-economic development have been running in an unequal pace throughout the newly formed Arab states even to this day. The strike for national self-awareness found non surprisingly the music as a significant conductor of ideas, an entrenchment of ethno-identical values, and fundamentally unique moral codes. As Hill and Wilson argue, in the strategy of showing the authenticity of one's group, separate approaches towards speech, creativity, and imagination can be used, leading to a timeless and ancient method of 
creating contemporary, live, popular and national art (Hill 2007, Wilson 1973). The interpretations of kind of national recognition has become extremely vital in art and music, providing an "infinity of different worlds" (Butt 2002, 17). In the last decades, the body of literature was dedicated to music and national identities (Turino 1999, Daughtry 2003, Buchanan 2006). The musical practice was observed and become shaped "not only by past experience, but also by ideas, feelings, and beliefs about the past" (Bithell 2006, 4). In this way, the recreation of tradition into a new material formed one of the most fundamental modern processes (Boden 2004, Lessig 2008). The music emerged as a delicate physiological and emotional network, linking several elements that encompass historical and cultural codes. These codes are recognized and adopted by the listeners and can be viewed as warm relations shaping the bond of multiple social and cultural affiliations (Trevarthen 1999), while producing a crosscultural phenomenon. Modern academia recognized the importance of the 'invisible hand' of the mass media in these processes, which firmly reshaped and continue reshaping the world of music. The influence is constant and ultimately transforms the local musical forms, thereby traversing them closer to a certain standard set by Western producers. Synchronically, throughout the past few decades, ethnomusicologists acknowledged the influential role of economic factors on the tendencies contouring the very core of pop music. As Feld argues, "whatever good it does, whatever pleasure it brings, it rests on economic structures that turn intangible cultural heritage into detachable labor" (Feld, 2012, 40). The commercialization of popular music is believed to be reinforced by the West's dominance and cultural centeredness that contributed to the Westernization and Globalization of the world's cultures (Inda and Rosaldo, 2008, 16\&17). Globalization and local semiotic play of oppositions 'hegemonic-authentic', 'hybrid-original' defines the subject matter of the paper, resulting from the modification of traditional music into a mixture of Western-orientated culture.

Initially in the twentieth-century Arab music productions were observed and regulated by local authorities. Auditors gained direct control over the music markets with the appearance of audio and video cassettes in the 1970s. Therefore, Arab music has converted into pop culture, where consumers constitute its meaning, tools, and presentation. Popular culture progressively turned into an "industrially made and distributed phenomenon" (Fiske, 1989, 23). The rise of technologies in the twenty-first century broadened the horizons. Yet, by presenting new possibilities, the popular culture influenced by foreign elements attacked the very foundation of traditional cultural content and the essence of the Arab musical legacy. Rihman-Augustin introduced a new term folklorismus describing a similar shift from folklore to a pop format, increasingly westernized and commonly treated as costumer product (Rihman-Augustin 1978, 165-166). That metamorphoses led to many changes in the highest expression of traditional Arab music. One of them is the obliteration of the spiritual link between mutreb (artist) and sami'ah (listeners). "Experience of culture today is no longer between a listener and work of music, a viewer and a painting; there is a whole host of people and technologies and networks that mediate between the people and cultural form" (Taylor, 2013, 760). However, regardless of the yearning for modernity and the leaning towards Western models of musical sound and visuals, Jordanian musiqa sha'abie, continues to stand firmly upon its local tradition. Folklore, as a legacy, "ensures that each generation will minutely restructure the music to fit its test and requirement" (Booth and Kuhn, 1990, 417,418); it shows the tendency to reach social and cultural entities, ensuring the genuine perception of belonging. Nevertheless, affection to a local sound does not exclude the out-bringing of new elements, borrowed from the West. Therefore, the inevitable transition of folk into pop is observed as a result of various driving forces, including economic, cultural, and market causes.

Religion, to this day, has a significant role in the governance of Arab states. Each Arab country includes theocratic aspects underwriting its constitutions, a reality that greatly impacts the culture, artistic approaches, and music therein. The existence of internet technology and mass media provoked a gradual transformation of the new generation's mindset regarding many taboos stemming from theocratic concepts and tribal traditions, including gender and sexuality (Frishkopf, 2010; Ghannam, 2013; Lohman, 2010, 135,136). Based on this reality, a more progressive perception of female singers has emerged. One that is yet utterly different from the former views of female tarab singers (e.g., Umm Kulthum and Fairus) dubbed as 'divas.' The conservative, old-standing disposition concerning female artists was observed by Nieuwkerk in "A Trade Like Any Other": Female Singers and Dancers in Egypt, who inferred on the regional sociology of female entertainment to discuss the situation of female singers and belly dancers in the Arab world. The author made a distinction between almeh (wedding dancer) and ra'asa (night club dancer). Nieuwkerk defined the latter as being associated by the society with "shame, and dishonor." Even today, the question mark of the sharaf (honor) applies to the image of the female artist in Arab society. Undoubtedly, modernity is modifying this social appearance into a new, free, and sexy cult figure. Such transformation, including contemporary videos of Arab female pop stars, triggered angry responses and accusations not only by conservatives but also by some scholars who blame the media for painting Western ideals in the minds of Arab youth. The discontent springs from their belief that expressing sexuality has never been a social norm in the Arab world. Some researchers defined the new pop video clips as "pornographic" (Kraidy, 2008) and declared the paradox of music visualization by how "predominantly male patrons crane their necks to watch attractive, semi-nude dancing females, while fully veiled women pass by their street" (Frishkopf, 2010, 31). These opinions have caused divisiveness in Arab society, the division between Western followers on the one hand, which 
defines themselves as multiculturalists; and liberals, thereby identifying themselves with the Western style of life and values, and traditionalists on the other. They are the once, who uphold the old, established traditional values and conservative norms. Unfortunately, this disunion has marked the gap between the poor, non-educated class, and those brought up in private schools and coming from urban and wealthy families. As noted by Barghouti, "the culture produced by television is that of the young Arab elite, a depoliticized, disengaged elite that seems to be coming from outer space" (Barghouti, 2010, 277). The deep penetration of religious values and canons into the everyday life affects the post-modern culture of Arab nations. Therefore, having in consideration everything what was summarized till now, the pop music evolved in front of our eyes as a conglomeration of different elements, which can be described as a consequence of tradition, history, religion, socio-economic inequality, localized aesthetics, political influences, neo-colonialism, globalization, technology, and massive invasiveness of Western values. All quoted aspects coalesce and shape the contemporary Arab pop music and musiqa sha'abie in particular.

\section{Jordan as an Independent Scene for the Development of Local Pop Culture}

The assentation of a distinct Jordanian musical identity is an important question that should be answered. The analyses of the responses will validate the proper bedrock on which will be grounded the further discussion concerning musiqa sha'ábie. Jordanian popular music can be described as a result of specific political, geopolitical, and historical forces. Thus, the local pop culture can be recognized as a mediator assisting in the establishment of a strong, singular homogeneous national identity. The strive for self-recognition can be pictured with the statement of Radue, who says that "There are particular musical and textual articulations that might be thought to distinguish [one] from others" (Pardue, 2004, 255).

Musical culture is generated by the creative process of individuals who enact norms and standards in response to the public demand. The artistic manifestation of the creator, whether consciously or not, projects the connotative query of the respective societal ecosystem and reflects the accumulated collective social subconsciousness. Therefore, the culture may be viewed as an image of self-determination and self-identification within a larger socio-micro-system. As Wilson notes, "a second diagnostic hereditary trait of human behavior is the overpowering instinctual urge to belong to groups in the first place" (Wilson, 2014, 30). Such creative processes compile individual human potential transforming it into collective potential, whereby producing indispensable cultural shifts. While defining the contemporary music of Jordan and its creative forces, one must highlight that the history of Jordan is trailed by a long chain of causality, resulting from distinct historical, social, and cultural stimuli. This trail can be tracked by the historical influence of neighboring peer nations; and colonial powers, such as the British Empire. Furthermore, it can be detected as a product of incremental developments, such as long spiritual evolution caused by the interaction with ancient cultures of Assyria, Babylonia, Ancient Egypt, Greek Poleis, Roman, and Byzantine Empires. Moreover, one may find common attributes stemming from the Edomites, Ammonites, Nabateans, and the Bedouin tribes. A pivotal period in the history of Jordan is the Islamic period and the advent of the Umayyad, and later the Ottoman Empire spanning from 1516 A.D to 1918 A.D. Trans-Jordan was established in 1922 as a protectorate of the British Empire and remained colonized until 1946, when it was transformed into the Hashemite Kingdom of Jordan. The political demands of upholding a sovereign statehood led to the necessity of creating a Jordanian identity. This process manifested itself as a response to a widely desired national unity, through which a consolidation within the multi-ethnic population of Jordan, containing Bedouin tribes, Palestinians, Circassians, Armenians, Christians, and Muslims, could finally be achieved. The process came about as an expected, subconscious drive, founded in the urge for survival within the borders of one of the smallest Arab countries, one of the poorest, and one with a relatively harsh climate. The construction of a nation in such conditions was not an easy task, and the popular culture became a part of this necessity, an arena where artistic creativity emerges to express national sentiments and ethnical identity. In this context, one can quote Friske, who said, "Culture is a living, active process; [which] can be developed only from within, it cannot be imposed without or above" (Fiske, 1989, 23). Indeed, the desire for self-determination is the key to understand the forces modeling modern Jordanian culture. In the Hashemite Kingdom, the impulse to show who you are and to what culture you belong, became the flag of contemporary music. "Most important is not that the music 'is' authentic in a way that it can be traced to real people playing music in traditional ways, but that it merely signifies this kind of authenticity" (Taylor, 2012, 177). In this sense, the music can be understood as an essential cognitive entity, that used all available tools to consolidate and construct a united national consciousness. Search for self-determination naturally found its pillar within the folk music, simultaneously fulfilling the society's strive for modernity with the creation of a specific sound, fuse of local and borrowings from foreign cultures.

Herein, discussing ethnicity, the next question naturally arises. Does the ethnicity define nationality, or whether borders and locality functionally lead to self-determination? Auslander argues that "authenticity is a matter of culturally determined convention, not an expression of essence" (Auslander, 1998, 9\&10). On one side, it can be stated that the collective social subconscious's urge for musical expression is not always in direct relation to the processes on a 'national' scale. On the other side, political necessity and social demand compulsory take their course at the deep psychological level within delicate networks of individual, community, ethnos, and nation, 
co-mingling in the formation of the cultural modus vivendi. Thus, popular music legitimately can be positioned as the nexus of national cultural life. The expression of ethnicity and its correlation to the local heritage is an aftereffect of establishing relations based upon the demand of self-determination. In the frame of the socio-cultural phenomenon in Jordan, the folk tradition entangled in popular culture should not be understood as one with an ancient origin, but rather as a contemporary invention related to recognition of specific cultural heritage, which can be engaged in the construction of unique national culture. "Modern Jordanian music is an expression of both culture and community; it is an expression of the deepest and most profound emotions of the Jordanian populous" (Ghawanmeh, 1997, 20). Moreover, Jordanian music is both geographically and socially defined. Martin Stokes argues that music "provides means by people to recognize identities and places, and the boundaries which separate them" (Stokes, 1997, 28). Many researchers have paid particular attention to the correlation between music and place, namely Cornnell, Gibson, Slobin, Stokes, Bell, and Benett. According to these scholars, people can produce a socio-cultural relation depending on the nature surrounding them, the landscape in which they live, the social group to whom they belong, and the ethnos from which they emerge. Hence, music is believed to be an expression of long-generational formation of specific emotional and aesthetic models, based on the so-called 'geography of the mind' (Ford, Henderson, 1978, 292). This notion resonates with Tuan's opinion that "space itself contracts our experience of space and is greatly extended by auditory sense which provides information of the world beyond the visual field" (Tuan, 1974, 9).

Besides the influence of locality and social contexts, the other significant force is strongly accumulated in the establishment of Jordanian culture. Namely, the long-standing tradition of foreign infiltration of ideas and aesthetics is apparent in the Arab Middle East's art. Since the Jahiliya (time of ignorance), a term given by Islamic scholars to describe the period before Islam, the assimilation of cultures was a result of the contact between the nomadic Bedouin zone and the settled counties surrounding it. The commercial intercourse between Arabs and neighboring Persia, Israel, Babylon, Syria, Ethiopia, Greek, and Roman states led to the infiltration of customs, norms, and finally, to hybridization of Arab culture. In the harsh, bare desert of Arabia, in the barren wideness, the Bedouin tribes developed tolerance and curiosity toward the outside world. The severe surrounding forced nomadic Arabs to commit continuous migration, turning them into traders, raiders, and conquerors, assimilating different civilizational practices faced in that endless path. This tolerance toward cultural diversity can be observed in the contemporary Jordanian popular music.

The following basis, which should be observed, is the specific coloring of the local culture. The musical heritage of Jordan and its surrounding countries was distinguished by Western academia as 'oriental.' Orientalism, as a semantic term, defined the relationships between the 'Orient' and the 'Occident' and was first coined by Edward Said (1979). Academic literature identified orientalism as the inherent variances within a culture in terms of both structure and self-manifestation. The following re-interpretation was spearheaded by theoreticians such as Todorova 1997, Hanks 2001, and Bakic-Haydn 1995. Regardless of the different connotations attached to the term, orientalism labeled Arab music as a definition toward a specific mixture of sounds, musical structure, distinct colors, and aesthetic self-impression. In this sense, Jordanian popular music is a typical representative of the oriental musical culture.

The last pillar on which the understanding of Jordanian culture can be grounded is that Jordan, being a country influenced by British colonial rule, is interpreted as an example of a post-colonial state. The late twentieth century brought about a boost in research concerning post-colonialism and cross-culture (Giddens, 1990; Hall, 1991; Richard Sennett, 2006). These studies showed particular concern toward the new type of capitalism, technologies, and their impact on globalization. Ray Chow argues that the popular concepts of pluralism and hybridity may be "grouped with dialogism, multiplicity as well as post-colonialism and cosmopolitanism" (Chow, 1998, 155), thus suggesting that cultural hybridity is the "legacy of colonialism understood from the viewpoint of the colonized" (Ibid, 1i5).In that connection, the comprehension of the fact that it is indisputable that "the economy is culturally inflected and that culture is similarly economically inflected" (Lash and Urry, 1994, 64) is vital. The colonial governance and the consequent influx of capital formed the dichotomy of 'self and others' which mapped onto the culture and social life in Jordan. Chester said that "Music as a practice has relative autonomy" (Chester 1990, 319), and consequently, countries that were part of a post-colonial legacy can easily adopt ideas of globalization and cross-cultural shifts. In this context, one can refer to Hayward, who notice that the foreign forces or "globalization can be understood not as a restriction but as a resource requiring particular product images and context to operate, and potentials far beyond those of the local market" (Hayward, 2012, 72). These cross-cultural processes, along with the attempt to be self-correct and ethnically faithful, define the present Jordanian musical life. Thus it is the invention of the new technologies (Sterne 2003), the growing tourism industry (Keightley 2004), the distribution of music (Brennan 2001), and capitalist expansion (Taylor 2007) together brought oriental and post-colonial Jordan into a new musical situation. A situation that can be described as provoked by multiple forces: locality, oriental aesthetic, historical effects, political necessities, and foreign influences is shaping the contemporary culture of one relatively new nation, namely Jordan. 


\section{Jordanian Musiqa Jadidah as an Expression of Local Tradition and Global Tendencies}

What is particularly illuminating about the local popular culture, is the effect of various external factors that have a considerable impact on its development; social trends, traditional causality, customary performance routine, political stimuli, economic realities, and globalization, discussed previously. In its comprehensive status, Jordanian contemporary music explicitly conveys the principal idea of ethnic unity, embedded within the collective consciousness of a nation. Music therein helps and solidifies a feedback loop whereby ideology is created and, therefor, swiftly entrenched within the social matrix of contemporary culture. Constitutional interpretations built upon parameters such as patriotism, nationalism, and localism have shaped its means and context. Whenever an urge of self-identification can be detected, a process of separating oneself from all others occurs. In this general sense, virtue identifying a national self-awareness is conceived through the victory of self-identity within the borders of one's historical, political, and geographic paradigm. In other words: "The most powerful practical problem is making sense of, fortifying, reconstructing, or saving our sense of self" (Kotarba, 2009, 68). One can identify similar social context within the Jordanian history and, respectively, in the contemporary Jordanian culture. When the Hashemite family came to power, they lacked the legitimacy and authority to speak or address a single unified nation. The Hashemite dynasty's first clash with local realities came after they attempted to unify nomadic tribes who inherited land based on a vague common law. These tribes included: Beni Hassan, Tarawneh, Adwan, Abbadi, Beni Saher, Srahan, Bani Haled, et al. Their tribal culture can be viewed as "a way of valorizing certain moral virtues [...] and thought to be the legacy of tribal social life" (Layne, 1989, 24). Each one of the nomadic tribes existed following its unique codes based on the Shari'a law, and often caused minor conflicts. The large diaspora of Armenian and Circassian settlers, and millions of Palestinian refugees, made any attempts of homogenization a complicated and daunting task. Consequently, music emerged as a mediator via which cultural homogenization could be accomplished. Thus, pop culture started forming by collecting features based upon local traditions and practices. The texts attached to music were dedicated to admiration of the King Hussein bin Talal (later Abdullah II bin Al-Hussein), the army, and national identity. In stark contrast to its neighboring countries, Jordan developed defending its own, newly established musical authenticity. In attempting to construct a united national culture, Jordan partly isolated itself from the post-cultural global trends, inducing occasional immunity toward possible cultural assimilation. Jordanian musiqa jadidah drifted towards Arab folklore, which can be easily remembered and recalled by the audience. In a way, this attachment to the folk heritage can be interpreted as traditionalism and "resistance to the hegemonic structures of established genres of modernity" (Briggs and Bauman $1992,149)$, or as a way of finding certain intimacy in a shared identity.

Local music theorists find the historical roots of the Jordanian songs in Gina' al Hurani, a type of choral performance which originates from the region of Horan located in the plains between Syria and Jordan. Ibn Khaldun (1334-1406) was one of the first to discuss this type of music: "it had four stanzas, whereby the first, the second and the third stanza differed, while the fourth stanza was in rhyme with the following stanza" (Ibn Khaldun, 2003, 586). Gina' Al Hurani is considered the origin of Jordanian Dabkeh (Chain Dance), which became the most popular genre in the country. Besides the Shami influence (Levant region; Palestine, Syria, Lebanon, and Jordan), local folklore has been significantly affected by the migration of Bedouin tribes between the vast desert plains of Jordan and Saudi Arabia. This migration contributed to specific impacts from the musical traditions of the Gulf region. Haddad discussed Jordanian folk songs saying that: "this singing comes from Al Joff region in Saudi Arabia, wherein songs such as Arda al Bariye hail from." (Haddad, 2003, 1668). Moreover, "In the Gulf region and Kuwait similar to Jordanian melodies are called Al Hadwah and Arda" (Ghawanmeh 1984, 231). These folk songs are performed in the manner of a dialogue where "the first group [singers] starts chanting the song in the form of recitation, and the second one repeats it accompanied by rhythmic feet clattering on the first strong beat" (Haddad 2003, 1670). Arda are commonly acted in the form of a dance Dabkeh, featuring an alternating rhythm, charged with enthusiasm, and joyful emotion. Jordanian songs are performed at any public event: weddings, engagements, and family gatherings. "It is not known who created them [the folk songs], who composed the melody or the lyrics. They have been handed down orally by the generations" (Kduri 1987, 35), and their simple structure, memorable tunes, and easily recalled texts make them catchy; "Jordanian folk singing is characterized by its uncomplicated musical structure" (Hamam 1998, 219). As a result, "over the years, some of this 'ahazeej (commonly known songs) have been repeated and re-arranged, yet using different lyrics" (Ghawanmeh, 1997, 78). Most of the Jordanian pop music resembles the Dabkeh, and is performed with or without instrumental accompaniment, but always supported by percussions. It is commonly performed by men; however, women increasingly take part in the chain dance.

Throughout the $20^{\text {th }}$ century, the urge to manifest ethnicity and belonging created a music expression of fixed social and musical stereotypes based on local heritage. Simultaneously, in the past few decades, new trends brought about by globalization came to light. One of the reasons for the contemporary globalizing effects over the Jordanian music is the political efforts exerted on the modernization and Westernization of education, and the introduction of information technology to the community. The other reason is the well-known thirst of the youth for trendy sound, up to date, and Western music. It is a challenging task to contemplate how multi-cultural can be interpreted 
in its relation to the aspiration of ethnic manifestation, and how the unified, cross-cultural sound can co-exist with local, oriental vibration. Globalization is in fact, is an inevitable force, modeling and shaping the cultural space of every country, as Trouillot reminds us, "we cannot easily discard the word 'globalization' in part, because just as modernity, it seems to point to phenomena not easily covered by other words" (Trouillot, 2003, 47). On a global scale, the modernity is not a single argument in favor of globalization's massive impact on music. Social, political, economic creative forces take place in that process. Simultaneously, the hybridity and multiculturalism act synchronically in the deepest level of collective subconsciousness, allowing us to construct a united world, based on similar esthetic norms. In the process of exchanging codes and symbols, virtually one can also deny other's power, instead willingly to assimilate foreign means and ideas. The young Jordanian generation has openly welcomed Westernization and Western aesthetic tastes into its own cultural space, despite its traditions and tribal codes. Globalization became a "label of modernity, which destroys locality and replays it with world market models" (Sparks, 2000, 70). The emphasis should come on the 'world market models.' Free access to technology opened new horizons to the millennium, driving the passion for examining others, imitating the others, being independent from old customs, and manifesting modernity. That is why Aziz could assert that "The young generation, especially in urban areas, are more tolerant of foreign ideas than the older generation" (Aziz, 2010,86). These deep mechanisms, constantly roaming beneath the surface of the socium, brought about stylistic borrowing, collaboration, and fusion between different cultures. The "power of music in today's shifting world" (Slobin, 1992, 1) became a significant force impacting the Jordanian community and art. This occurrence can be illustrated by Taylor's theory concerning the development of global pop music under the effect of global markets. This collaboration of elements can be presented as a sociological phenomenon. Being armed with this new positionings, the folk template of Jordanian song has been transformed, thereby becoming an object within the context of social stereotypes and consistent dynamic stream, 'typified by fragments 'from outside' and 'from inside,' with influences of local and global nature" (Negus 1996, 138). Throughout the integration process between city and village music, folk and modernity, Jordanian music evolved into a unified urban pop model. The existence of specific popular culture in Jordan can be described as a self-admitted expression of an implicitly own culture, within the global scale or postmodernity, what can be validated by the statement of Dunn: "the modernity was about overcoming internal conflicts that divided the self, whereas postmodernity celebrates fragmental identities" (Dunn, 1998, 29\&33). In the context of globalism, Jordanian pop music cannot be isolated to a 'one-way traffic,' as highlighted by Taylor, Hall, and Barker. It can be understood as a two-ways process, observed by Feld and Charles: "All of this complicated traffic of sounds is two-way dialogic. While watching some inter-ethnic interrelations, we can say that American music is becoming Africanized, but African music is also AfroAmericanized." (Feld and Charles 1994, 239).

While discussing Jordanian music, it should be pointed out, that the power of its popular music is hidden in the articulation of social issues, through the events, sounds, and experiences interlaced into the songs. Therefore, Jordanian music can be understood figuratively as a strong voice manifesting the strength of the family, religion, and national unity. For instance, in the original work 'Clash of Civilizations, 'Huntington's first step in identifying the principles of globalization applied to the Singaporean community was defining the nation's fundamental values. He listed Singaporean society's values as followed: the nation as an ethnic unity, family being the basic block of society, and the importance of religious harmony. Similar presumptions can be applied to the Jordanian society. Unsurprisingly, this assumption can be found in the motto of the Hashemite Kingdom of Jordan, "God, Country, King." Arabs, as an ethnos, never wholly accepted or bluntly denied the encroaching effects of globalization. The Arab youth, technologically educated and inclined to modernity, willing accepts and approves globalization trends, while at the same time remaining attached to its ethnic roots. Thus, as all their peers, young Jordanians are highly influenced by modernity and Western products.

It is safe to say that there are two main genres in the frame of Jordanian popular music. The division of the popular Jordanian culture on two main groups, Franko and sha'abie, is presented accordingly to the widely accepted between musicians and general public separation of pop music. The first one is often referred to pundits as Franko, or what was earlier defined as Arab pop. Musiqa franko is mostly based on maqamat; it uses oriental rhythms and Arab musical elements mixed with Latino, hip-hop, or rap rhythms. It is greatly influenced by Western tendencies, electronically rendered sounds, unified esthetic, when the lyrics often narrate romantic plots, or social issues. In general, Franko is in sync with modern regional trends of musiqa jadidah. Music videos of Musiqa Franko are remarkably similar to what one might see on MTV, featuring dance choreography and beautiful dynamic scenery. Representatives of musiqa franco are artists such as: Prof. Dr. Ayman Tayseer, Diana Karazon, Hani Mitwassi, Lina Sleibi, Luai Hadjazeen, Synaptic, Shab el Jdeed, Naser Mesttarihi, Toni Qattan, and Mahmoud Radaideh. However, it should be noticed that within musiqa franko, unusual currents and dynamics can be observed, and many different genres and streams are apparent. Genres included under the label of Franco vary significantly one from anther, also some artists shift from style to style in search of a new interpretation within the Arab pop. For example, singers known as representatives of musiqa tarab, can present songs or concerts in ethnojazz (Lina Sleibi, Ayman Tayseer). Farah Siraj can smoothly move between Latino-pop to ethno-jazz. Naser 
Maesttarihi, who is a famous Franko representative, operates within a hard rock stream. Shab el Jdeed and Synaptic, the new generation music icons, singing in clubs and live shows, can be classified as hip-hop musicians. The diversity of genres, united under single term Franko and the division of contemporary Jordanian music into just two major streams, can be explained with the objective cultural differences toward expressing and perceiving music. From the Jordanian point of view, music is acknowledged and separated into two entities based on the perception of ethnic boarding and cultural distinction. This demarcation can be asserted as a token, providing insight into how locals distinguish music. The first approach is toward recognizing a local, ethnic music, collecting and generating meaning, and suggesting traditional and native heritage. Second is toward Franko, or other music, that is categorized as influenced by foreign cultures, product of assimilated modern forms, multi-styled music, adapted to the local test.

The other dominant genre, namely Musiqa Sha'abie, consists of songs that are based on folklore elements, featuring throwbacks to popular franko songs. It is fast-paced music, synchronic to al dabkeh. The simple texts of musiqa sha'abie aim to build up national sentiments and pride. The maqamat used are predominantly in major scales, thus inducing an optimistic mood and impression. The preeminence of percussion instruments makes these songs catchy and easy to dance. The presentation and video aesthetics of musiqa sha'abie tend to be simple and conservative. The social life in Jordan still follows the traditional Bedouin principles, and religion (whether it be Christianity or Islam), and it is built on multiple gathering, part of which is the performance of musiqa sha'abie. Musiqa sha'abie is recognized and accepted by all social, religious, and age groups; this is the music listened to during family events, weddings, and social occasions. Representatives of this style are Ahmad al Daraysah, Issa Al Saqar, Omar al Abdallat, and Hussein el Salman.

\section{Musical Features of Jordanian Musiqa Sha'abie}

It was stated that the cornerstone of Jordanian pop music is musiqa sha'abie, built upon national motifs and references to local heritage. This music is an expression of the attempt to create a unique musical tradition that stems from the mid-twenty century and displays a correlation with Bedouin chauvinism. Musiqa sha'abie can be characterized as energetic, brisk, fast-paced, and based on a dance rhythm otherwise known as dabkeh. This genre is performed during social gatherings, national celebrations, or family meetings. It is the type of music that is a part of everyday life for the people. Regardless of individual tastes in music, Jordanians of all ages and from all walks of life listen and recognize musiqa sha'abie as their music. Most people who have lived in Jordan can agree that whenever sha'abie music is played, almost all Jordanians spring up to their feet and begin chain dancing in an exuberant radiance of collectivism, optimism, and hopefulness. The distinguishing factor of sha'abie music is its oriental esthetic, mixed with tinges of Western pop elements. The following list of characteristics can further define musiqa sha'abie:

- The modality is the feature that distinguishes musiqa sha'abie from any other contemporary forms of popular culture. The Arabic word for mode is maqam or maqamat in plural. Maqam is linguistically defined as 'position'; however, in music, it is interpreted as a set of notes arranged in terms of scale. The Arabic maqam system is a broad subject and displays multiple aspects. It was influenced by Persian, Asian, and Greek music. The academic approach to the maqam system commenced after Ancient Greek philosophers' theses were translated (approximately around $623 \mathrm{CE}$ ), whereby Arab musical theory fostered the Greek theoretical model. The maqam system was derived from Al Farabi (872-950), who wrote one of the most influential books in Arab music history: Kitab Al Musiqa Al Kabir (The Grand Book of Music), wherein he defined the theoretical framework of the maqamat. It should be pointed out that maqamat are broadly diverse and are quite numerous. However, in contemporary Jordanian music, the most commonly used maqamat are Al-Rust, Al-Hijaz, Al-Nahawand, Al-Ajam, Al-Kurd, Al-Bayat, and Al-Saba. A defining factor of Arabic maqam theory is the existence of intervals shorter than halfnotes, referred to as kar flat and kar sharp. These intervals are mainly responsible for the oriental coloring of the music and its distinctive sound. Although Arabic maqamat are unequally tempered structures, "they were adapted to harmonization" (Signell 1977, 46). Contemporary pop music's harmonization is built upon the rules of Western harmony, predominantly resting on the vertical approach rather than the traditional horizontal understanding of the musical process in musiqa tarab. This shift in the musical structure serves as a reflection of Bruno Nettl's argument that "the modernization can be described as incidental movement in the system or its component in the direction of Western music" (Nettl, 1985, 20). This new custom toward harmonization of the music led to the modification of the oriental sound at its core, thus shifting it closer to the Western expression.

- Arab musical culture, including musiqa sha'abie, is correlated to al turath or "the historical faithfulness to the past' (Kenyon 1988, 6). Turath al musiqa is the musical knowledge handed down from generation to generation, from father to son, from mother to daughter, and is defined as tradition. Through turath al musiqa, one can acquire a better understanding of the local folklore, or what may be described as the eminent imprint of ethnic culture. "Musical turath (heritage) describes the specifics and psychological 
basis of the social development and the culture" (Al Huli, 1996, 180). Therefore, contemporary Jordanian culture must be interpreted while considering the importance of oral folk heritage as the pure essence and collective expression of belonging, sharing beliefs, customs, and art forms.

- Urab (ornamentation), is yet another unique aspect of Arabic music. Jordanian sha'abie is rich in melismatic elements that are often found in instrumental introductions and vocal performance. The $u r a b$ technique is displayed in the specific way of singing, when main notes are richly ornamented, and essential words or longer values are produced by the traditional approach of 'vibrating' around the prime sound with quarter tones embellishment. Nonetheless, it should be noted that musiqa sha'abie is less ornamented than musiqa al tarab. The mere fact that can explain this difference is that musiqa al-sha'abie is based on the folklore and is closely related to dabkeh's pace.

- Taqasim, otherwise known as Arabic improvisation, form another critical aspect of musiqa sha'abie as a part of Arab oriental music. Paragraphs left for solo interludes are never written down in the note script, as traditionally, every performer is expected to implement his/her improvisational discretion into the musical body. The ability to express emotions through music in a way to interacts with the audience and is of great importance to Arab musicians. Taqasim can be somewhat similar to jazz improvisation or "jumping into the deep end of the pool with the option of sinking or swimming" (Herzig and Baker, 2014, 196). The art of improvisation is essential to the extent that Arabs tend to favor singers able to perform taqasim, referring to them as mutrebeen, as opposed to mughanniyeen, who are unable to perform improvisation. Taqasim is commonly executed within major parts in the form and as requested by the audience. It can be completed from the instrumentalists or the singer, and is widely implemented in musiqa sha'abie, especially live performances.

- Arab music, including musiqa sha'abie, originally stood along with an aesthetic imperative settled by narrative rules and canons per the virtue of the hadith (precedents of the prophet Mohammed). For centuries Islamic religious leaders declared vocal music the purest form of art, whereas instrumental music was condemned. This rule led to the development of a specific vocal technique that is highly ornamented and technically challenging. "The predominance of vocal music naturally grew out of the attitude toward music as a tool for the conveyance of ideas. Vocal music, by its intimate association with words, carried and interpreted thoughts and feelings, while instrumental music, according to Semitic Oriental conception, serves only as accompaniment and embellishment" (Idelsohn, 1956, 18). Therefore, musiqa sha'abie is predominantly vocal and strongly associated with the textual context.

- A 'multi-voice authorship' can describe the standard for identifying the author status as a creator of the musical process in Arab music. Customarily, Arab music requires several people to construct an artistic work, for instance, one to compose a melody, another to create an instrumental arrangement, and a third to perform it. In contemporary Western pop music, a similar division occurred at the end of the twentieth century; "The removal of the Author is not merely a historical fact or an act of writing; it utterly transforms the modern text" (Barthes, 1977, 145). Regarding Arab music, this tradition is embedded in the customs steaming from ancient times. Brakett succinctly defines the Arab musical 'builders' as: "songwriter, instrumentalist, arranger, producer, and singer, all leading to a multiplicity of voices (Brackett, 2000, 16\&17). The multi-authorships remain strong to this day. Within Jordanian musiqa sha'abie, there is a clear division between the roles of each party taking share in the creation of the musical product. Thus, the multi-authorship can be divided into a composer of the melodic line- mulahen, arranger of the instrumental parts-muazzi, lyric writer, composer-muallef, singer-mutreb, instrumental performers- mutrebeen, sound engender- muhandes souti, and producer- mudir an intadj.

- Arab music is based on the vertical compositional plan; the quintessence thereof is to emphasize the importance of melodic line, and lyrics. Throughout the ages, oriental music has mostly committed to developing diverse melodic archetypes, in contrast to Western musical paradigms, which have constantly evolved more sophisticated and complex horizontal structures. The maqam system treats each musical idea as a continuum of time and melodic linkage, whereby modal and rhythmical changes are incorporated without compromising the continuity of melodic lines. Given that contemporary trends, and thrive for change within the musical paradigm, it comes as no surprise that attempts toward creating a vertical structure for Arabic music are ordinarily praised. In Jordanian musiqa sha'abie, the harmonic arrangements, borrowed from Western music, are based on simple chord progressions, which serve to enrich the overall sound. Simultaneously, "traditional melody and functions must undergo transformation in order to be mapped on Western harmony and repackaged for global consumption" (Bohlman 2003, 21).

- The structure of musiqa sha'abie does not correspond with that of ballads and rhapsodies in the classical Arabic musiqa al tarab. Ancient poetic genres such as Shi'r, Hida, Samri, and Nashid left an essential impact on text writing of the old Arab generation. The end of the $20^{\text {th }}$ century and transformation toward the Western model of composition led to the adoption of other approaches penetrating the rhythm, 
intonation, and text. The influence of folklore also impacts the music converting the songs and poetry to simpler and shorter samples. Therefore, it can be observed that the primary characteristic of Jordanian sha'abie song is a short phrase, elementary wording, and melody, repetitions, and simplicity in all forms. This metamorphosis can be detected in the adoption of shorted and basic structures as $\mathrm{AB}$ or Rondo form, in most of the songs.

- Sha'abie music is based on the so-called 'sual-jawab' tradition, or the question-answer pattern whereby a musical motif is performed by the singer and then repeated by an orchestra or by a choir. This method was borrowed from the dabkeh and arda folk songs.

- Traditional instruments such as $u d$, qanun (trapezoid zither with 72 strings), nay (reed flute), and darabukah (ceramic vase-shaped drum) are staples of classical Arabic music, and thus of Jordanian pop music. These instruments grant the specific, oriental character of the songs. The unique modes, expression, and technique implemented in the instrumental art carry distinct codes and meanings to the locals. In his book, Michael Zager accurately described the distinctiveness of ethnic instruments by stating that "the use of ethnic instruments required a complete understanding of the nature of the instrument. There are typical patterns and ornamentation that are native to the playing of a particular instrument" (Zager, 2003, 24). In the past few decades, however, a hybrid mixture of Western and Arabic instruments was adopted into Jordanian pop musical space. Western instruments incorporated in the traditional spectrum of local music are the org (electric piano), violins, and guitars. Embodiment of such instruments provide the actual hint to modernity. Initially, the electronic piano saw general distrust and was approached with caution, as it was believed to be subpar of classical Arabic maqamat and the foundational principle of scales built upon the scheme of the quarter notes. "This [the cautious use of synthesizers] has been discussed during the Arab Music Conference in Cairo, 1932” (Racy 1991,76). Despite the initial mistrust, the electric keyboard has become a primary instrument in contemporary Arab pop music. Other widely used instruments are the violin, cello, saxophone, and classical guitar. Musicians who were pioneers in the adoption of these instruments into Arabic music are: Farid al-Atrash, Said Darwish, and Mohammed Abd al-Wahhab. In contemporary musiqa sha'abie the application of org is so crucial that one cannot imagine a song, without the accompaniment of keyboard.

- The folk roots of contemporary Jordanian culture have been thoroughly discussed in this paper, considering both historical and cultural perspectives. The existence of folk motifs in musiqa sha'abia can be interpreted as nostalgia toward one's heritage and as a tool for preserving self-determination and ethnic belonging. As Zaharieva argues, therefore, "Folk music is a sign of cultural identity, 'a scream' of other rivaling trans-individual subjects" (Zaharieva 1995, 262). Sha'abie aims to prove its unique identity as opposed to it being washed away by contemporary franko music. This aim can be understood as a storing message against total homogenization, which can be confirmed by what Eriksen stated: "Nobody is quite certain what it means to be Berliner, a Malaysian or a Norwegian anymore, but this does not mean that these identities are going away. Some of them are in fact, strengthened" (Eriksen, 2005, 26). Folk elements, observed in musiqa sha'abia, are the tunes, closely associated with the local customs of the distinct intonational way of building the horizontal as a melodic line, the specific oriental rhythm, the short phrases structure similar to folk ahazeej, the limited interval range in the vocal, and the lyrics.

- Iqa' $a,($ rhythm) is one of the most critical building blocks of sha'abie music. The rhythm is always energetic and moderately fast, accompanied by percussions, and can be characterized by the vast use of syncopation and uneven beats. Rhythms in the Arab theory of music are referred to as iqa'at and are consistent with strict rhythmical modes. A set of primary rhythms are defined and applied to different maqamat and forms. The most commonly used rhythms in sha'abie are: Ayoub 2/4, Samai Saghier, 3/8, Valz Draj, 3/4, and Baladi $4 / 4$.

- Contemporary sha'abie lyrics (qalimat) are represented by the lack of romanticism, in contrast to classical musiqa tarab or musiqa franka. The texts revolve around the national identity. Musiqa sha'abie is collective communal music; thus, it carries symbols of masculine power and symbolism of Jordanian integrity. Lyrics are written in the common tongue lugha a'mma and are simplistic. The topics commonly include an homage to the King and royal family, military, and national pride. The texts are bright, optimistic, and gravitate around the individual, community, matrimony, and family.

\section{Conclusion}

Throughout the course of this paper, the key characteristics of Jordanian sha'abie music have been made apparent. These features distinguish the researched object from the global world music scene. In conclusion, it may be asserted that Jordanian sha'abie has some distinctive traits. From one aspect it strives to stay true to tradition and cultural heritage, serving as a continuum to local ethnic identity, whereby al-turath stands in contrast with the subcategory al jaded 'the novel' music, which deliberately and consciously open new horizons to non-traditional influences, including music impact "outside the sphere of Arab music altogether "(El Shawan 1980, 86). Musiqa 
sha'abie developed by constructing a new self-understanding, absorbing partial repercussions from the Western musical paradigm, while remaining faithful to its tradition. This unique nature of musiqa sha'abie stems from its ontological nomos and vitality. Sha'abie music is made for the people, and by the people, in assistance and aspiration to recognize belonging to a country, cultural tradition and ethnos, a kind of "affirmation of local citizenship" (Yudice, 2003, 114). Musiqa sha'abie simultaneously presents the features of semiotic musical hybridity, and cosmopolitan way of thinking. This Jordanian contemporary popular culture is directed towards joy, gratification, celebrating modernity and homogeneity, but expressing itself through local musical elements. It has looked outwards, presenting the spirit of the global soul, while maintaining in its hart traditional and self-absorbed. From a global perspective, one can observe musiqa sha'abie as a sample of hybridity and as a new kind of music, proclaiming authenticity; or as Turino has confirmed that, "authenticity and hybridity are not opposed to one other" (Turino 2008, 137). Thus, Jordanian sha'abie music appears as a paragon of ethnic tradition, a pillar of national self-identification, as well as a bridge towards the postmodern culture of the West. As a result, the paradoxical nature of Jordanian musiqa sha'abie makes a compelling case for the continued study of popular music genres in this ever-increasingly globalized world.

\section{References}

Al Huli, S., (996), The Arabic musical culture and the changes in originality and its modernization, Majallet al alem al fikri. Vol.25 /1, Egypt

Auslander, P., (1998), Seeing is Believing: Life performance and the Discourse of Authenticity in Rock Culture, Literature and Psychology, Vol.44/4

Aziz, M., (2010), Arab Music Videos and Their Implication for Arab Music and media In Music and Media in the Arab World, American University in Cairo Press

Baker, G., (2011), Buena Vista in the Club: Rap, Reggaeton, and Revolution in Havana, Duke University,

Barghouti T., (2010), Critique - Caliphs and Clips', In Michael Frishkopf (ed.), Music and Media in the Arab World, Cairo: American University,

Barthes, R., (1977), The Death of the Author, In Image-Music-Text, London

Bithell, C., (2006), The past in Music: Introduction In the past of music, Ethnomusicology Forum Special issue, Vol. $15 / 1$

Bhabha, H.K., (1994), The location of Culture, London, Routledge

Boden, M., (2004), The Creative Mind: Myths and Mechanisms, New York, Routledge

Briggs, C., Bauman, R., 1992, Genre, Intertextuality and Social Power, Journal of Linguistic Anthropology, Vol. $2 / 2$.

Brackett, D., (2000), Interpreting Popular Music, California University Press

Bohlman P., (2003), World music: A very short Introduction, Oxford University Press

Booth, G., Kuhn, T., (1990), Economic and transmission factors as essential elements in the definition of folk, art and pop music, The Music Quarterly Vol. 74/3

Burdon, J., Neff, A., (2016), Sounding global Southerners, Journal of Popular Music Studies Vol $27 / 4$

Butt, J., (2002), Playing with History; The Historical Approach to Musical Performance, Cambridge University Press,

Chester, A., ([1970] 1990) Second thoughts on a rock aesthetic; The band. In On record: Rock, pop and the written word. Ed. Simon Frith and Andrew Goodwin, New York, Pantheon.

Chow, R., (1998), King Kong: Postcolonial China, Duke University Press

Daughtry M., (2003), Russia's New Anthem and the Negotiation of National Identity, In Ethnomusicology, Vol 47,1

Dunn, R.G., (1998), Identity Crises: A Social critique of Postmodernity, University of Minnesota Press,

El Shawan, S., (1980), The social political context of al musiqua al arabiyyah in Cairo, Egypt; policies, patronage, institutions, and musical change 1927-1977, Asian music Vol. 12/1,

Eriksen, T., (2005), How can the Global be Local? Islam and West and the Globalization of Identity politics, Sweden, University of Gothenburg,

Erlmann, V., (1996), The Aesthetics of the global imagination: Reflections on World Music in the 1990s, Rubric Culture, University of Chicago.

Feld, S., Charles, K., (1994), Music Grooves, Chicago Press,

Feld, S., (2012) My Life in a Bush of Ghosts: "World Music" and the commodification of a religious experience', In Music and Globalization, Indiana University Press.

Fiske, J., (1989), Understanding Popular Culture, Boston, Unwin Hyman,

Ford, L.R., Henderson, F.M., (1978), The Image of Place in American Popular Music 1890-1970, In G.O. Carney (ed).

Frith, S., (2007), Taking Popular Music Seriously, Aldershot Ashgate

Frishkopf, M., 2010, Music and Media in the Arab World. Cairo, AUC Press 
Ghannam, F., (2013), Live and Die like a Man: Gender Dynamics in Urban Egypt, Stanford University Press

Ghawanmeh, M., (1997), The melodies of Jordan", Rozana, Amman

Ghawanmeh, F., (1984), Songs of Kuwait, Markaz al turath al Shaabi li dual al Khalij, Kuweit

Gilman, D., (1914), Cairo Pop: Youth Music in Contemporary Egypt, University of Minnesota Press

Ibn Khaldoun,([1988] 2003), Books of Lessons, Record of Beginnings and Events in the History of Arabs and Barbers and Their Powerful Contemporaries, Second Edition, Daar al Fikr Al Arabi, Lebanon

Idelsohn, A., (1956), Jewish Music in Its Historical Development, New York, Schocken Books

Inda, J., Rosaldo, R., (2008), Tracking Global Flows, The Anthropology of Globalization: A Reader, Oxford: Blackwell Publishing

Haddad, Abd S., (2003), The song of Dabkeh al Djoufieh, In Majallet Abhath al Yarmouk, Vol.19, 3B, Irbid, Jordan

Hamam, Abd H., (1998), Music, songs, and the ways of teaching them, Vol. 2, Manshurat jamaat al Quds al maftuha, Palestine

Hayward, P., (2012), A place in the world: Globalization, Music and Cultural Identity of Contemporary Vanuatu, In Music and Globalization, Indiana University Press

Herzig, M., Baker, D., (2014), Beyond Jamming: A Historical and analytical perspective of the Creative Process, Journal of the Music and Entertainment Industry Educators Association, Vol.14/4, Belmond University

Hill, J., (2007), Global Folk music fusions: The reification of Transnational Relationships and the Ethics of Crosscultural Appropriations in Finnish Contemporary Folk Music Yearbook for Traditional Music, Vol.39

Kelly, T., (1989), Early Music in America. A Report on a survey conducted by Early Music America, New York, Ohio State University Press

Kenyon, N., (1988), Authenticity and Early Music, Oxford University Press

Kotarba, J., (2009), Pop Music as a resource for assembling an authentic self. A Phenomonological - existential perspective, In Authenticity in Culture, Self and Society, Ed. Philip Vannini and J. Patrick Williams, Farnham, UK, Ashgate

Kraidy, M., (2008), Reality Television and Politics in the Arab World: Preliminary Observations, In Transnational Broadcasting Studies, Vol. 16

Kduri, H., 1987, A Small musical encyclopedia, Sherikat al mansur le tibaa, Bagdad

Layne, L., (1989), The dialogs of tribal Self Representation in Jordan. American Ethnologist, Vol 16/1, Blackwell Publishing

Lash, S., Urry, J., (1994), Economies of signs and space, London, Sage publications

Lessing, L., (2008), Remix: Making Art and Commerce Thrive in the Hybrid Economy, New York, Penguin Press

LeVine, M., (2008), Heavy Metal Islam: Rock, Resistance, and the Struggle for the Soul of Islam. New York: Three Rivers Press.

Lohman, L., (2010), Umm Kulthüm: Artistic Agency and the Shaping of an Arab Legend, 1967-2007. Middletown, CT: Wesleyan University Press

Mutaz, A., (2010), Arab Videos and their implications for Arab Music and Media, In Music and Media in Arab World, American University in Cairo Press

Negus, K., (1996), Popular Music in Theory, University Press of New England, Hanover

Nettl, B., (1985), The Western Impact on world music: change, adaptation and survival, New York, Schirmer Books

Nieuwkerk, K., (1995). A Trade like Any Other: Female Singers and Dancers in Egypt. Austin: University of Texas Press

Pardue, D., (2004), Putting Mano to Music, The Meditation of Race in Brazilian Rap, Ethnomusicology Forum, Vol $13 / 2$

Racy, A., (1991), Historical worldviews of early ethnomusicologist: an east - west encounter in Cairo 1932 , Ethnomusicology and Modern Music History, Urbana and Chicago

Rihman-Augustin, D., (1978), Tradition, Folklore, and Mass Culture in Yugoslavia, In Folklore in the Modern World, Hague, Mouton Publishers,

Said, E., (1979), Orientalism, New York, Pantheon

Signell, K., (1977), Makam: modal practice in Turkish art music, Washington D.C. Asian Music Publications

Slobin, M., (1992), Micromusic of the West: A comparative approach. Ethnomusicology, Vol. 36/1

Sparks, C., (2000), The Global, the Local and the Public Sphere. In New Communication Landscape: Demystifying Media Globalization, London, Routledge

Stokes, M., (1997), Introduction: Ethicality, Identity and Music, Oxford University Press,

Taylor, T., (2012), World Music Today, Music and Globalization Critical Encounter, Indiana University Press

Taylor,T., (2013) Globalized New Capitalism and the Commodification of the Taste, In The Cambridge history of world music, Cambridge Press

Taylor, Ch., (1994), Multiculturalism: Examining the politics of recognition, Princeton University press 
Trevarthen, C., (1999), The Origins of Music, Musicae Sciaentiae, Cambridge University Press

Trouillot, M. R., (2003), Global Transformation: Anthropology and the Modern World, New York, Palgrave Macmillan

Tuan Yi-Fu, (1974), Topophilia: A study of Environmental Perception, Attitudes and Values, Columbia University Press

Turino, T., (2008), Music as social Life, University of Chicago Press

Wilson, E., (2014), The meaning of human existence, Liveright publishing

Wilson, W., (1973), Herder, Folklore and Romantic Nationalism, Journal of Popular Culture, Vol. 6 /4, Croatia, Yudice, G., (2003), The Expediency of Culture: Uses of Culture in the global era, Duke University Press

Zaharieva, S., (1995), Musical Folklore Study of Nationalism. View to the Past, Meaning of the Present, Bulgarian Musicology, Vol. 1, Sofia

Zager, M., (2003), Writing music for Television and Radio Commercials: A Manual for Composers and Students, Lanham

Tsonka Al Bakri is an associate professor at the University of Jordan, College of Fine Arts and Design, Music Department. She graduated from Bulgarian School of Music "Lubomir Pipkov," Bulgarian Academy of Music "Pancho Vladigerov" instrumental faculty piano, and Ph.D. in musicology. Since the age of 9, she performed solo recitals and concerts with orchestras in Europe and Russia and Turkey and has two gramophone records and one CD. After her transfer to Jordan she performed many concerts and became a piano teacher at the National Music Conservatory, Yarmouk University, when she established the piano department and later at the University of Jordan. She is an author of more than 20 researches in national and international journals covering ethnomusicology, musicology, and methodology. Her scientific work focused mainly on Arab ethnomusicology, piano performance, teaching, and history of music. 